\title{
MOTHER'S KNOWLEDGE AND PARTICIPATION IN MEASLES RUBELLA (MR) IMMUNIZATION FOR TODDLERS
}

\author{
Haspita Rizki Syurya Handini ${ }^{1}$, Yussie Ater Merry ${ }^{2}$, Dhina Khairina ${ }^{3}$ \\ ${ }^{1,2,3}$ Padang Health Polytechnic, Health Ministry, Indonesia
}

\section{INFORMASI ARTIKEL:}

\section{Riwayat Artikel:}

Tanggal diterima: September 2020

Tanggal di revisi: September 2020

Tanggal di Publikasi: Oktober 2020

Key Word : MR Immunization, Knowledge, Level of Education, Attitude, Employment, Number of children

\begin{abstract}
A B S T R A C T
Measles rubella (MR) immunization is to provide immunity against measles and rubella. To reduce measles and rubella, the government carried out the MR immunization campaign. The target of MR immunization achievement is at $95 \%$; however, in West Sumatra Province it is still at 38,98\% and Padang City is at $47 \%$. The purpose of this study was to determine the determinant factor as participation in MR immunization for toddlers. This analytic survey used a cross sectional study design. The population was mothers who had toddlers with a sample of 86 respondents taken by proportional random sampling technique. The instrument used was a questionnaire. Data processing was analyzed by bivariate and multivariate using chi square test and logistic regression. The results of the bivariate analysis showed factors related to MR immunization, namely knowledge $(p=0.003)$, level of education $(p=0.006)$, and attitude $(p=0.006)$, while employment $(p=0,222)$ and number of children $(p=0,160)$ were not related to MR immunization and the most influential variable was the level of knowledge with $\mathrm{p}$ value 0.009 and OR 0.28 . It can be concluded that knowledge, education and attitude are related to maternal participation in MR immunization with the most influential variable being knowledge. Therefore, there needs to be innovation in providing counseling to mothers and families about the importance of MR immunization.
\end{abstract}

\section{INTRODUCTION}

Indonesia is one of the countries with the most cases of measles and rubella in the world. In 2014 to July 2018, there were 57,056 suspected cases of measles and rubella reported, and in 2015-2016, there were 226 cases of Congenital Rubella Syndrome (CRS) in newborns. To reduce the incidence of measles and rubella, starting in 2017 the government has added the MR vaccine as routine immunization, in accordance with the agreement of the WHO countries (Dirjen P2P, 2018).

Mothers play an important role in giving immunizations to children. Many factors that greatly influence mothers to participate in immunization are, among others, mother's knowledge level, attitudes, beliefs, values, traditions, and others such as education level, family income, number of children in the family and family support (Soekidjo Notoatmodjo, 2007).

Mother's knowledge and education will influence their attitude in making decisions to provide additional immunizations such as MR to their children. Therefore, the number of children and free time owned by working mothers also determines the participation of mothers in immunizing their children (Merlinta, 2017).

Based on the results of the preliminary observation at one of the Health Center in Padang City, out of 10 mothers who had toddlers, only 3 of the mothers participated in the MR immunization. This then became the background for research on the determinant factors of mother's participation in providing MR immunization to toddlers.

*Korespondensi: haspita.rizki@gmail.com 


\section{METHOD}

This was an analytic survey study with a cross sectional design. It was conducted in the working area of a community health center. The population in this study were 833 mothers who had toddlers aged 12-59 months at 16 Posyandu (health post either for toddlers). Sampling was proportional random sampling with a total sample of 86 people. The data source used was primary data obtained through a structured questionnaire to assess knowledge, education, attitudes, occupation and the number of children. Bivariate analysis employed the ChiSquare test with a $\mathrm{p}$ value $<0.05$, and then the variables in the bivariate analysis which had a $p$ value $<0.25$ would be followed by multivariate analysis with logistic regression tests.

\section{RESULT AND DISCUSSION}

Based on table 1 below, it can be seen that, of the 47 mothers with low knowledge, $72.3 \%$ did not participate in the MR immunization. The results of statistical tests with Chi-Square obtained $\mathrm{p}$ value $=0.003(\mathrm{p}<0.05)$; of 10 mothers with basic education, $80 \%$ of them did not participate in MR immunization; of 57 mothers with secondary education, $63.2 \%$ did not participate in MR immunization. Of more than the 19 respondents with advanced education, only $26.3 \%$ of mothers did not participate in giving MR immunization to toddlers and obtained $\mathrm{p}$ value $=0.006$.

\section{Table 1. Relationship between Mother Characteristics and Participation in MR Immunization}

\begin{tabular}{|c|c|c|c|c|c|}
\hline \multirow{3}{*}{ Characteristics } & \multicolumn{4}{|c|}{ Participation } & \multirow{3}{*}{$\underset{\text { value }}{\mathbf{p}}$} \\
\hline & \multicolumn{2}{|c|}{ No } & \multicolumn{2}{|c|}{ Yes } & \\
\hline & $\mathbf{f}$ & $\%$ & $\mathbf{f}$ & $\%$ & \\
\hline \multicolumn{5}{|c|}{ Level of knowledge } & \multirow{3}{*}{0.003} \\
\hline $\operatorname{Bad}(<$ mean $)$ & 34 & 72.3 & 13 & 27.7 & \\
\hline Good ( $\geq$ mean) & 15 & 38.5 & 24 & 61.5 & \\
\hline \multicolumn{5}{|c|}{ Level of education } & \multirow{4}{*}{0.006} \\
\hline Basic & 8 & 80 & 2 & 20 & \\
\hline High School & 36 & 63.2 & 21 & 36.8 & \\
\hline Univ & 5 & 26.3 & 14 & 73.7 & \\
\hline \multicolumn{5}{|l|}{ Attitude } & \multirow{3}{*}{0.06} \\
\hline Negative & 33 & 71.7 & 13 & 28.3 & \\
\hline Positive & 16 & 40 & 24 & 60 & \\
\hline \multicolumn{5}{|l|}{ Employment } & \multirow{3}{*}{0.222} \\
\hline No & 8 & 42.1 & 11 & 57.9 & \\
\hline Yes & 41 & 61.2 & 26 & 38.8 & \\
\hline \multicolumn{5}{|c|}{ Number of children } & \multirow{3}{*}{0.160} \\
\hline At risk & 14 & 73.7 & 5 & 26.3 & \\
\hline Not at risk & 35 & 52.5 & 32 & 47.8 & \\
\hline
\end{tabular}

Based on the research results, it shows that there was a relationship between the level of mother's knowledge and participation in giving MR immunization to toddlers, with a $p$ value of 0.003 ( $\mathrm{p}$ value $<0.05$ ). There was a relationship between the mother's level of knowledge and the participation of the mother in giving immunization for toddlers in accordance with the theory that someone will act based on knowledge. This is because knowledge is a very important domain for the formation of one's actions.

The results showed that there was a relationship between the level of maternal education and the participation of mothers in providing MR immunization with a $\mathrm{p}$ value of 0.006 ( $\mathrm{p}$ value $<0.05)$. This was because mothers who have advanced levels of education are thought to be easier to receive and understand information about immunization.

Based on the results of the analysis with the Chi Square statistical test, the results obtained was a 
$\mathrm{p}$ value $=0.006(\mathrm{p}<0.05)$, so it can be concluded that there was a significant relationship between maternal attitudes and participation in giving MR immunization to toddlers. Parents' attitudes have a relationship with immunization. Differences in the attitudes of mothers have a significant relationship with the behavior of giving immunization: mothers who have negative attitudes have a greater chance of having negative behaviors including immunization.

The results showed the Chi Square test with a $\mathrm{p}$ value of 0.222 ( $p>0.05$ ), so there was no significant relationship between maternal occupation and participation in MR immunization. According to the theory of Pandji Anoraga, working mothers will have less opportunity and time to come to immunization services so that children will not get immunizations. The researcher assumed that the mismatch between the results of this study and the theory might be due to the fact that most of the working mothers were private workers, so that the mothers could spend time on the Posyandu schedule so that they could still provide immunizations to their children.

The results showed the Chi Square statistical test with a $p$ value of 0.160 ( $p>0.05)$, so it can be concluded that there was no relationship between the number of children and participation in giving MR immunization to toddlers. Lienda's 2009 research in Rica Novi stated that The number of living children $\leq 2$ people had 1.19 times their children to be fully immunized compared to those who had more than 2 living children. The greater the number of children, the more likely it is that the immunization is inaccurate to the child.
Table 2 Preliminary Modeling

\begin{tabular}{|l|l|l|}
\hline No. & Variable & $\boldsymbol{p}$ value \\
\hline 1. & Education & 0002 \\
\hline 2. & Knowledge & 0.002 \\
\hline 3. & Attitude & 0.003 \\
\hline 4. & Employment & 0.138 \\
\hline 5. & Number of children & 0.096 \\
\hline
\end{tabular}

Table 3 Final Modeling

\section{Step 1}

\begin{tabular}{|c|c|c|c|c|}
\hline & Variable & Coefficient & $p$ & OR (CI 95\%) \\
\hline \multirow[t]{9}{*}{ Step 1} & $\begin{array}{l}\text { Level of } \\
\text { education }\end{array}$ & & 0.068 & \\
\hline & Education (1) & -2.308 & 0.047 & $0.10(0.01-0.97)$ \\
\hline & Education (2) & -1.736 & 0.029 & $0.18(0.03-0.83)$ \\
\hline & Level of & & & \\
\hline & knowledge & -1.195 & 0.027 & $0.30(0.10-0.86)$ \\
\hline & Attitude & -786 & 0.132 & $0.46(0.16-1.27)$ \\
\hline & Employment & 964 & 0.225 & $2.6(0.56-12)$ \\
\hline & Children & -5.60 & 0.403 & $0.57(0.15-2.1)$ \\
\hline & Constanta & 1.521 & 0.015 & 4.56 \\
\hline \multirow[t]{8}{*}{ Step 2} & $\begin{array}{l}\text { Level of } \\
\text { education }\end{array}$ & & 0.050 & \\
\hline & Education (1) & -2.417 & 0.034 & $0.09(0.01-0.8)$ \\
\hline & Education (2) & -1.805 & 0.022 & $0.16(0.03-0.7)$ \\
\hline & Level of & 1155 & & $0.32(0.1100$ \\
\hline & knowledge & -1.155 & 0.032 & $0.32(0.11-0.9)$ \\
\hline & Attitude & $\begin{array}{r}-807 \\
857\end{array}$ & 0.121 & $0.44(0.16-1.23)$ \\
\hline & Children & & & \\
\hline & Constanta & 1.541 & 0.014 & 4.67 \\
\hline \multirow[t]{6}{*}{ Step 3} & $\begin{array}{l}\text { Level of } \\
\text { education }\end{array}$ & & 0.067 & \\
\hline & Education (1) & -1.849 & 0.063 & $0.16(0.02-1.10)$ \\
\hline & Education (2) & -1.310 & 0.034 & $0.27(0.08-0.9)$ \\
\hline & $\begin{array}{l}\text { Level of } \\
\text { knowledge }\end{array}$ & -1.018 & 0.048 & $0.36(0.13-0.99)$ \\
\hline & Attitude & -826 & 0.108 & $0.44(0.16-1.20)$ \\
\hline & Constanta & 1.748 & 0.004 & 5.74 \\
\hline \multirow[t]{5}{*}{ Step 4} & Level of & & 0.034 & \\
\hline & Education (1) & -2.030 & 0.039 & $0.13(0.02-0.90)$ \\
\hline & Education (2) & -1.459 & 0.017 & $0.23(0.07-0.7)$ \\
\hline & $\begin{array}{l}\text { Level of } \\
\text { knowledge }\end{array}$ & -1.267 & 0.009 & $0.28(0.10-0.73)$ \\
\hline & Constanta & 1.582 & 0.008 & 4.87 \\
\hline
\end{tabular}




\section{Step 2}

\begin{tabular}{|c|c|c|c|c|}
\hline & Variable & Coefficient & $p$ & OR (CI 95\%) \\
\hline \multirow[t]{7}{*}{ Step 1} & $\begin{array}{l}\text { Level of } \\
\text { education }\end{array}$ & & 0.067 & \\
\hline & Education(1) & -1849 & 0.063 & 0.157 \\
\hline & Education(2) & -1.310 & 0.034 & 0.270 \\
\hline & Level of & & & \\
\hline & knowledge & -1.018 & 0.048 & 0.361 \\
\hline & Attitude & -826 & 0.108 & 0.438 \\
\hline & Constanta & 1748 & 0.004 & 5.742 \\
\hline \multirow[t]{5}{*}{ Step 2} & $\begin{array}{l}\text { Level of } \\
\text { education }\end{array}$ & & 0.034 & \\
\hline & Education(1) & -2.030 & 0.039 & 0.131 \\
\hline & $\begin{array}{l}\text { Education(2) } \\
\text { Level of }\end{array}$ & -1.459 & 0.017 & 0.233 \\
\hline & knowledge & -1.267 & 0.009 & 0.282 \\
\hline & Constanta & 1.582 & 0.008 & 4.863 \\
\hline
\end{tabular}

The final result of the multivariate analysis showed that, with the level of knowledge was the highest variable, the value of the $\mathrm{B}$ and OR coefficients were -1.267 and 0.282 , respectively. This means that the knowledge level variable had an effect of 0.282 times compared to other variables. These results indicated that the level of knowledge was the most dominant variable associated with participation in giving MR immunization to toddlers..

\section{CONCLUSION}

The participation of mothers who have toddlers in giving $\mathrm{MR}$ immunization is influenced by several factors, including the level of knowledge, education level, and mother's attitude. Mothers who have good knowledge and have an open attitude towards immunization tend to participate in giving MR immunizations to their toddlers. For this reason, posyandu cadres and health workers should increase activation in health promotion such as counseling to increase the knowledge of mothers regarding MR immunization.

\section{REFERENCE}

Budiman, Agus Riyanto. 2013. Kapita Selekta Kuesioner Pengetahuan dan Sikap. Jakarta Selatan : Salemba Medika.

Dirjen P2P. 2018. Petunjuk Teknis Kampanye Imunisasi Measles Rubella (MR). Jakarta :
Kemenkes RI. 2017. [sumber online].

Tersedia dari :http://www.searo.who.int/indonesia/. Di akses 20 Agustus.

Gayuh Mustika P,dkk. 2018. Beberapa Faktor yang Berhubungan dengan Penerimaan Ibu terhadap Imunisasi Measles Rubella pada Anak SD di Desa Gumpang Kecamatan Kartasura Sukoharjo. [Jurnal] Kesehatan Masyarakat Volume $6 \quad$ Nomor 4. Universitas Diponegoro.

Hartoyo,dkk. 2011. Studi Nilai Anak yang Diinginkan, dan Keikutsertaan Orang Tua Dalam Program KB. [Jurnal] Ilmu Keluarga dan Kons IPB Volume 4 Nomor 1.

Lailan, Najah. 2017. Tingkat Pengetahuan Ibu Tentang Imunisasi Tambahan MR (Measles Rubella) Pada Balita di Puskesmas Kotagede I Yogyakarta. [Skripsi] Prodi DIV Bidan Pendidik Universitas Aisyiyah Yogyakarta.

Maryunani, A. 2010. Ilmu Kesehatan Anak dalam Kebidanan. Jakarta: Trans Info Media.

Merlinta. 2017. Hubungan Pengetahuan Tentang Vaksin MR (Measles Rubella) dan Pendidikan Ibu Terhadap Minat Keikutsertaan Vaksinasi MR di Puskesmas Kartasura. [Skripsi] Prodi Pendidikan Dokter UMS.

Nelfrides. 2016. Faktor Risiko Kejadian Campak pada Balita di Kota Padang Tahun 2015. [Skripsi] FKM UNAND.

Proverawati,A. 2010. Imunisasi dan Vaksinasi. Yogyakarta : Nuha Medika.

Soekidjo, Notoatmodjo. 2007. Promosi Kesehatan dan Ilmu Perilaku. Jakarta : Rineka Cipta.

Rica,Novi. 2016. Hubungan Jumlah Anak Dalam Keluarga dengan KelengkapanImunisasi Anak di Desa Sukowiryo KecamataJelbuk Kabupaten Jember. [Skripsi] Prodi Keperawatan Universitas Jember. . 
The Southeast Asian Journal of Midwifery Vol. 6, No.2, Oktober 2020, p: 87-91

Wawan, A dan Dewi,M. 2011. Teori dan

Pengukuran Pengetahuan, Sikap dan

Perilaku Manusia. Yogyakarta : Nuha Medika 